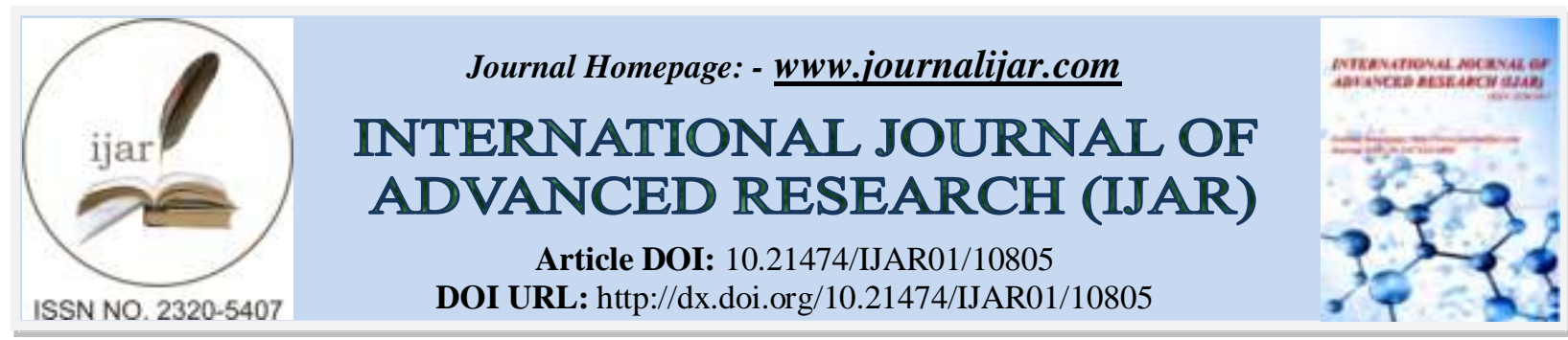

RESEARCH ARTICLE

\title{
THE PEASANT MOVEMENTS OF ANCIENT WORLD AND THEIR BASIC TRAITS WITH NATURE: A RETROSPECTIVE DISCOURSE
}

\author{
Dr. Kamal Chandra Pathak
}

Associate Professor, Department of History, Sonapur College, Kamrup Metro, Assam-782402 (India).

\section{Manuscript Info}

\section{Manuscript History}

Received: 10 February 2020

Final Accepted: 12 March 2020

Published: April 2020

Key words:-

Insurrection, Encompass Ed,

Ecclesiastical, Manorial, Pastures,

Escalated, Assertive, Arable, Scarce,

Pillaged, Destitution

\section{Abstract}

While we deal with the nature and basic traits of the peasant movements of ancient world; we come across several instances which project the nature and character of various peasant movements of the world. This research-based paper is an endeavor to present a brief picturesque of peasant movements of various parts of ancient world along-with their traits and nature.

\section{Introduction:-}

The year of 579, saw a major peasant insurrection which was directed against the rule of Chilperich, the Merovingian king, in the course of which many peasants in the vicinity of Limoges left their holdings to escape excessive tax burdens. Tax collectors were threatened with death by the infuriated mob. So, at the end, military force was used to stop the rebellion. The biggest peasant rebellion in Carolingian times occurred in 841 , when the peasants of Stellinga in Saxony protested against the Frakish type of feudal rule. In Saxony which had only recently been subjugated by the Frankish rulers, the process of feudalization was much slower than in the other provinces of the Frankish empire. Therefore, the conventional social structure of nobles, freemen and half-free survived longer in Saxony than elsewhere in the empire. The position of freemen and half-free who had fought most persistently against the Frankish conquerors, had deteriorated markedly with the invasion of the Franks and the introduction of their rule. Encouraged by open dissent among the sons of King Louis 'the pious', the Saxon freemen and half-free arose in a big rebellious movement between 841 and 843. This Stellinga movement encompassed both dependent and free peasant groups, and was primarily directed against lay and ecclesiastical manorial lords whose position had improved since the Frankish conquest to the detriment of the peasantry. It took King Louis and the Saxon nobility several extremely violent campaigns to suppress the insurrection, which had spread over large parts of Saxony.

The resistance of the peasants against the heavy demands of the manorial lords grew in the medieval period with the rise of urban centre and the intensive development of landed resources. The frequent disputes of peasants with their lords concerning rights to woodlands and pastures lasted for several years. In 1210, a conflict was, finally settled concerning the use of the woodlands between the monastery of Salem and the peasants of Oberzell, a village to the north of Lake Constance which had lasted for several years. It had escalated particularly in 1198 when the inhabitants of Oberzell devastated a farm of the monastery at Adelsreute, an action for which they were sentenced to heavy punishment. A conflict which was also related to the use of the Commons was recorded between the abbey of Himmerode and a number of its villages. It was above all the peasants of Dudeldorf, Pickliessem and Gindorf who felt defrauded of their traditional right to use a large stretch of woodland, as a result of which they attacked a farm belonging to the monastery, seized its cattle and threw stones at the lay servants of the monastery. It was only after the inhabitants of the villages concerned faced with the possibility of being excommunicated; a compromise 
between the conflicting parties was reached in 1228, which put an end to the aggression on both sides. Similar struggles between assertive peasant communities and manorial lords, who tried to restrict their rights to the Commons, were also recorded in many other regions during the 13th century. The number of conflicts grew as arable land became scarce with the intensified development of land resources, a trend which incited many feudal lords to try and raise their revenues by limiting peasant rights to the Commons.

In the 13th and 14th centuries, peasant communities clashed with ambitious rulers, especially, in the Alpine provinces and along the coastlines of the North Sea where the rural population had fought hard to obtain a relatively independent social position and far reaching autonomy in communal matters. In the 13th century, the peasant insurrections and even the long peasant wars shook particularly such regions as Drente, West and East Frisia, the Stedingerland and Dithmarschen. The insurrection of Stedingers was one of the most impressive peasant revolts of the medieval ages. The Stedinger communities in the lower Weser area waged a major war against the archbishops of Bremen and the counts of Oldenburg in an effort to preserve their freedom. Yet although they fought for years; they were not as successful and the Frisians and eventually lost against the combined forces of their enemies.

The Flemish revolt lasted for several years from 1323 to 1328 . The principal targets of this revolt were lay manorial lords and administrative abuses by tax collectors and administrative officials. The centers of the revolt were the coastal areas of Flanders where the peasants had won considerable independence in the high middle ages. It started in the vicinity of Bruges during the winter of 1323, and was, at first directed against the excesses of the judicial authorities who charged taxes and court fees in an arbitrary manner. The struggle against these individual abuses soon developed into a universal protest of assertive peasant communities who held much more far reaching goals. In their rage, the rebels launched their assaults, mainly, on the castles of the nobility, which were often pillaged and destroyed in the course of revolt. Without meeting any serious opposition, the revolt soon affected the entire province and found the support of all towns except Ghent. The office-holders of the courts were replaced by representatives from the peasant estate, who maintained the normal administration for years. The decisive blow against the rebels, eventually, came from an army sent by the king of France at the request of the Count of Flanders. After a big battle near Cassel in 1328, the Flemish peasant army was forced to surrender to the French Knights and 'this defeat marked the final collapse of the insurrection.

The Jacquerie of 1358, which was essentially a revolt caused by peasant destitution, was unique because of its surprising geographical spread over a very small time span. Heavy tax demands, the vast devastation of the country as a result of the hundred years war and innumerable lootings by impoverished mercenaries had driven the defenseless peasantry to despair. Faced with the wretchedness and insecurity of their condition, the peasants were allowed to form their own defense units to repulse the assaults of vagrant mercenary gangs. In the last days of May, 1358 , an open insurrection started in the Beauvais region which soon spread into Picardy and other neighboring areas. In many places, the rebellious peasant troops, which for the most part operated independent of each other, forced procrastinating individuals to join them. Great bitterness was felt towards nobility which only pursued its own interests and often participated in pillaging the countryside rather than protecting the peasants and their villages. Hence, the peasants answered with destruction of many castles and mansions, often driving away the owners. Most towns, however, were undecided and only a few of them were active supporters of the revolt. It was soon plain that the insurrection was highly spontaneous in character and lacked a political perspective, for it collapsed after a few months despite its vast geographical extent.

The German peasant revolts in the late middle age became much more frequent in the late 14th and 15th centuries, and had a much greater political impetus than their forerunners. In the 14th century, only 4 major peasant revolts were recorded while this number increased to 15 in the first half and then to 25 in the second half of the 15th century. These revolts mainly occurred in the south of Germany.

In south-west Germany, the grave consequences of the agrarian crisis induced many lords to strengthen the ties of personal lordship over their peasants so as to prevent them from moving elsewhere as well as to compensate for losses in income by charging higher dues. But around the year 1370, a serious conflict developed between the monastery at Hauenstein and its peasants concerning the terms of serfdom which finally, culminated in an insurrection. The peasants had sought to escape from monastery by moving in to towns and refusing to pay the dues connected with their status as bondsmen. After years of conflict, a legal agreement was reached in 1383 which permitted the peasants to move in to those towns which acknowledged that it was legitimate for the monastery to 
demand the payment of heriot. In cases where a bondsman failed to obey this rule, the monastery was entitled to confiscate both his movable and immovable property.

There was scarcity of labour following the depopulation after the Black-Death in England. The land-owners had a lot of land in their hands which required tilling. Many land-owners had to take recourse to hired-labour where as they relied on the manorial villeins before the plague. Hired laborers were not abundant at that time which put them in a very commanding position. The landlords found it difficult to cope with the situation and therefore, they appealed to parliament to eradicate the problem through some form of legislation. 'The Statute of Labourer' passed by the parliament in 1351, sought to offer remedies in the event of the situation precipitated by the Black-Death, but in reality, it was an indirect attempt to give the land-owners control over labourers even in the changed conditions. Indeed, the Statute was highly impractical in the context of the situation that existed after the plague. In the course of the implementation of the Statute, there was a strong ignition as it forced the labourers to be tied to the land. Once again, labourers who fled their employers were branded as falsity. The Statute of Labourer was one of the instruments that provoked the peasants to revolt against the oppressive working standards. Such provocation touched its pinnacle when another oppressive poll tax was imposed on the peasants. The rising originated from an unpopular poll tax. Its oppressive and corrupt administration caused local revolts in Essex and Kent which became the signal for a national rebellion.

In 1377, the parliament imposed a poll tax of a groat or four-pence on all English people above 14 years, except beggars. Two years later in 1379, there was an enhancement to the tax which was now increased on the wealthier nobility while a peasant was required to pay a groat as earlier. In 1380, however, the matters became worse when a new tax of three groats was imposed on all persons above fifteen, irrespective of their condition. The peasantry was incensed by this tyrannical poll tax and within months there was a consolidation of the public against it. The first outbreak of the revolt took place in Kent when one Wat Tyler murdered a tax collector and marched to Canterbury. He headed a large group of protestors who destroyed many manorial records that came to their way. According to Trevelyan, 'the revels invaded the manor houses and abbeys, extorted the right they claimed and burnt obnoxious charters and manor rolls.

Spontaneous revolt took place in Hertfordshire and Essex. Riots started entire England and the basic demands of the rioters were the abolition of the institutions of villeinage, freedom to the peasants and access to markets. One of the drawbacks of the revolt was that it took place in the towns. The Archbishop of Canterbury was murdered; the tower of London was looted and countless justices and manorial heads were assaulted and manhandled. Such violence did not help the peasants to arrive at their objects. The murder of Wat Tyler by London's Mayor caused the spark for the revolt to run-out. Soon, Richard II,the king of England was able to quell the revolt within three weeks of Tyler's death. The king and the nobility did not keep the promises that they made and the abolition of villeinage was pushed further in to the future.

According to Trevelyan, the rebellion had been a great incident and its history throws a flood of light on the English folk of that day. Historian cannot decide whether it helped or retarded the movement for the abolition of freedom, which continued at much the same pace after 1381 as before. But, the spirit that had prompted the rising was one of the chief reasons why serfdom died out in England as it did not die out on the continent of Europe.

The Knight revolt of 1523 was followed by a peasant revolt in Germany. Leopold Von Ranke called the peasant war of 1525 as 'the outstanding natural phenomenon in German history.

The peasant class in Germany had been fully exploited and the clergy too had a share in this. The peasants had social and economic grievances and finally, the religious ferment added fuel to the fire on it. As a result of which, the movement assumed serious proportions. Headed by fanatics, various groups of peasants freely indulged in ghastly acts of crimes. Martin Luther saw in this revolt the possibility of a danger to the reform movement and so, it was put-down. The peasants did not like the Protestants as they suppressed their revolt with the help of the princes of German states. The medieval peasant was not a tenant in the modern sense of the term; rather he was dependent on or subject to his lord in a variety of ways. A powerful factor of peasant existence in medieval feudal society was the bondage to the feudal lord. Until German peasants were emancipated in the 19th century, majority of them dependent on feudal lords who were entitled to various tributes and services. Taxes had to be paid upon marriage and death; on St. George's and St. Martin's Day; and in spring and autumn. Pathetically, little remained for the 
peasants in years of bad harvests and even in normal years, the remaining supplies only allowed for a modest livelihood.

G. Franz regards each and every peasant revolt of the 14th and 15th centuries 'as a precursor of the peasants' war of 1525.' Even, Peter Blickle, the author of the most recent comprehensive study of this event has also endorsed this view.

Predominantly, during the Tokugawa period, Japan was an agricultural country. More than $80 \%$ of the total population accepted agriculture as their principal profession. The government revenue was mainly collected from the poor peasants to maintain the government and support the idle samurais. This led to a chronic economic distress in the country which ultimately culminated in peasant uprisings. The economic growth of the merchants was highly responsible for the deterioration of the peasants' economy. The stability of a society depends mainly upon its sound economic system. But the history of Tokugawa period was a stay of growing dissatisfaction with economic conditions. It gradually undermined the era of stability inaugurated by the early Tokugawas. With the emergence of township and merchant community, the peasant economy met a great setback. This economic discontent found their expression in numerous peasant uprisings in Japan. These peasant uprisings, gradually gained momentum during the time of floods, drought and adverse price of commodities. No provision was made 'for import of food grains from other countries to relieve the starving millions at that time of the failure of crops' which culminated their anger.

Abolition of feudalism in 1871 in Japan directly affected the farmers. The peasants were now freed from the feudal obligations and became free holders. There was also a drastic change in the system of revenue collection. During the feudal regime, taxes were collected in kind according to the value of the crops; and the peasants were left with no more than just enough to live on. Thus, the feudal lords were the real care-takers of the peasants in the sense that in the time of need, they used to help the peasants under their jurisdiction. But under the new government after the abolition of feudalism, the taxes were collected in cash according to the value of the land. Moreover, the peasants were not forced to stick to their land. They were at liberty either to remain on their land or sell it out and leave for the city.

The Agricultural conflicts popularly known as 'Swing Riots' took place in England in 1830-31.The production of agriculture came down heavily following the Napoleonic wars and even after that. The matter was far from improving. Poor harvests and increasing prices bitterly affected the British economy which led to labour unrest creating a complicated and difficult situation. Unemployed number had risen and a collective dissatisfaction found manifestation in the agricultural disorders, the first of which began in Kent in 1830. The unrest speedily spread to other areas of England. The name 'Swing' associated with the riots was derived from Captain Swing, who led the rioters by writing anonymous letters. Loss of property and the destruction of equipments were common. About 2000 of the protesters were arrested and 19 were hanged. Though the riot was quickly curbed but despite that, it brought some issues relating to agricultural and working conditions into sharp focus and was influential in bringing the Reform Act of 1832. The Swing Riots also highlighted other social discrepancies by involving the general population in the affected areas.

The economic condition of China during the Manchu rule was, partially responsible for the outbreak of Tai-Ping rebellion in China which continued from 1851 to 1864 under the leadership of Hung Hsiu-Chuan. It was basically a peasant movement. There was economic dislocation due to accumulation of land in large holdings. There was no equal distribution of land; and the poor peasants, the real tillers of the soil, were put to the mercy of the landlords for a piece of land. The situation was further aggravated by the profit- mongering merchants who used to hoard foodgrains in huge quantity until the price was raised abnormally. The situation was worst confounded by the increase of population. The increase of population without corresponding increase of arable land caused acute food-shortage which affected the poorer section of the people most. Large scale importation of finished foreign goods also shattered the rural economy of China. It affected cottage industries which was subsidiary to agriculture of the local craftsmen and small traders. Another economic factor which was especially injurious to the tax payers was the sudden increase of the value of silver in comparison to copper. As the agricultural tax was calculated in silver but paid in copper, the tax burden of the peasants increased heavily. Thus, the economic mal-adjustment in the country infuriated millions of poor and unprivileged who were out to join the rebellion.

The economic distress was further worsened by floods and famine in South China. The people of Kwantung and Hunaor provinces suffered a lot due to recurring floods which caused constant failure of crops. Finally, starvation 
and malnutrition broke the morale of the people. The corrupt government machinery failed to tackle the situation to redress the minimum grievances of the hungry millions. The people came out to join the rebels in large number out of utter dejection. It made the confusion more confounded. This revolt was, practically, a crusade against feudalism; and its aims and objects was to re-distribute land among the Chinese, taking into consideration its productivity. The rebels attempted to dissolve the big land-holdings for improving the condition of the poor peasants but failed miserably. 